\title{
АНАМНЕСТИЧНІ КЛІНІКО-ПСИХОПАТОЛОГІЧНІ ОСОБЛИВОСТІ ДЕПРЕСИВНИХ ПРОЯВІВ У ПАЦІЄНТІВ ІЗ КОГНІТИВНИМИ ПОРУШЕННЯМИ ПРИ ДЕПРЕСИВНИХ РОЗЛАДАХ
}

\begin{abstract}
Анамнестичні клініко-психопатологічні особливості депресивних проявів у пацієнтів із когнітивними порушеннями при депресивних розладах

\section{С. О. Ярославцев}

Комунальне некомерційне підприємство «Херсонський обласний заклад з надання психіатричної допомоги Херсонської обласної ради»
\end{abstract}

Резюме. Актуальність проблеми депресій зумовлена не тільки поширеністю і дезадаптуючим впливом патології, а й тим, що своєчасна діагностика цих розладів у багатьох випадках стає вирішальною умовою успішної медичної допомоги. Тому дослідження, спрямовані на вивчення анамнестичних даних щодо особливостей початку депресії і тривалості хвороби до моменту звернення до лікаря у хворих із когнітивними порушеннями при різних типах депресивних розладів, $\epsilon$ актуальними та дозволяють покращити критерії діагностики, що сприятиме підвищенню ефрективності лікування.

Мета дослідження - визначити анамнестичні клініко-психопатологічні особливості депресивних проявів у пацієнтів із когнітивними порушеннями при депресивних розладах.

Матеріали і методи. Було обстежено 362 пацієнти із когнітивними порушеннями при депресивних розладах: 123 осіб із рекурентними депресивними розладами (РДР), 141 пацієнт із біполярними афрективними розладами (БАР) та 98 осіб з пролонгованою депресивною реакцією (ПДР). Використовували комплекс методів дослідження: клініко-психопатологічний, клініко-анамнестичний та статистичний.

Результати. Були встановлені специфрічні особливості перебігу депресивного розладу в пацієнтів із когнітивними порушеннями при різних типах депресивних розладів: при РДР відзначалось переважання підгострого та затяжного початку депресії; тривалість депресивного епізоду від 3-х до 6-ти місяців; переважання 3-5 та 1-2 епізодів в анамнезі; тривалість ремісії від 12-ти до 24-х місяців. При БАР відзначалось переважання гострого та підгострого початку депресії; тривалість депресивного епізоду від 6-ти місяців до 1 року; переважання 3-5 та більще 5-ти епізодів в анамнезі; тривалість ремісії від 6-ти до 12-ти місяців; при ПДР відзначалось переважання затяжного та підгострого початку депресії; тривалість депресивного епізоду «до року»,
Anamnestic clinical-psychopathatological features of depressive manifestations in patients with cognitive impairments in depressive disorders

\section{S. O. Yaroslavtsev}

Communal Nonprofit Enterprise "Kherson Regional Institution of Mental Care of Kherson Regional Council" e-mail: kalenskaya_galina@ukr.net

Summary. The urgency of the problem of depression is due not only to the prevalence and maladaptive effects, but also the fact that timely diagnosis of these disorders in many cases becomes a crucial condition for successful medical care, so research to study the anamnestic data on the onset of depression and the duration of the disease in patients with cognitive impairment in various types of depressive disorders is relevant and will improve the criteria for diagnosis and improve the effectiveness of treatment.

The aim of the study - to determine the anamnestic clinical and psychopathological features of depressive manifestations in patients with cognitive impairment in depressive disorders.

Materials and Methods. 362 patients with cognitive impairment in depressive disorders were examined: 123 patients with recurrent depressive disorder (RDD), 141 patients with bipolar affective disorder (BAD) and 98 patients with prolonged depressive reaction (PDR). A set of research methods was used: clinical-psychopathological, clinical-anamnestic and statistical.

Results. Specific features of the course of depressive disorder in patients with cognitive impairment in different types of depressive disorders were established: in RDD there was a predominance of subacute and prolonged onset of depression; duration of a depressive episode from 3 to 6 months; predominance of 3-5 and 1-2 episodes in the anamnesis; duration of remission from 12 to 24 months. The predominance of acute and subacute onset of depression was noted in $B A D$; duration of a depressive episode from 6 months to 1 year; predominance of 3-5 or more 5 episodes in the anamnesis; duration of remission from 6 to 12 months; in patients with PDR the prevalence of the long and subacute beginning of depression was noted; duration of a depressive episode "up to a year", "up to 1.5 years" and "up to 2 years"; predominance of 1-2 episodes in the anamnesis; duration of remission more than 24 months. 
«до 1,5 року» та «до 2-х років»; переважання 1-2 епізодів в анамнезі; тривалість ремісії більше 24-х місяців.

Висновки. У результаті дослідження були визначені особливості перебігу депресивного розладу в пацієнтів із когнітивними порушеннями при різних типах депресивних розладів, які можуть виступати в якості діагностичних критеріїв при проведенні дифреренційної діагностики та бути мішенями фрармакотерапії та соціальної реабілітації.

Ключові слова: пацієнти 3 когнітивними порушеннями; депресивні розлади; клініко-психопатологічні особливості; рекурентний депресивний розлад; біполярний депресивний розлад; пролонгована депресивна реакція.

\section{ВСТУП}

Депресія - одна з провідних проблем у сучасній охороні здоров'я і за поширенням займає друге місце [1-3]. За даними Всесвітньої організації охорони здоров'я, депресія розцінюється як провідна причина непрацездатності та четверта в рейтингу захворюваності [1, 2, 4]. Відповідно до останніх епідеміологічних даних, депресія виявляється у всіх країнах і серед усіх етнічних і расових груп [1, $5,6]$, що становить від 10-15 \% для жінок і від 5$15 \%$ у чоловіків $[1,4]$.

Дуже важливим аспектом депресивних розладів (ДР) є суїцидальний ризик $[1,7]$. Приблизно 2/3 пацієнтів із діагностованою депресією схильні до суїцидальних спроб і близько 800000 осіб помирають через самогубство щороку [2, 6, 7]. Депресія $€$ клінічно неоднорідним станом із значно недооціненою різноманітністю симптомів, що охоплюють емоційні, фрізичні та когнітивні сорери [4, 8, 9].

Актуальність проблеми депресій, що спостерігаються в загальномедичній практиці, зумовлена не тільки поширеністю і дезадаптуючим впливом патології, а й тим, що своєчасна діагностика цих розладів у багатьох випадках стає вирішальною умовою успішної медичної допомоги [8, 10]. На сучасному етапі розвитку науки і практики виявлення та класиорікація депресій в умовах загальномедичної мережі пов'язані зі значними складнощами $[6,9,10]$. Це зумовлено наявністю «маскованих» форм депресій, стертої картини депресивних розладів, складною коморбідністю з соматичною патологією, рецидивним перебігом захворювання, ускладненням депресії когнітивними порушеннями (КП) і неточністю в діагностичних критеріях оцінки депресивного стану [11-13]. Тому дослідження, спрямовані на вивчення анамнестичних даних щодо особливостей початку депресії і тривалості хвороби до моменту звернення до лікаря у хворих із КП при різних типах ДР, є актуальними та дозволяють покращити критерії діагностики, що сприятиме підвищенню есрективності лікування різних типів ДР.
Conclusions. The study identified the features of the course of depressive disorder in patients with cognitive impairment in different types of depressive disorders, which can act as diagnostic criteria in the differential diagnosis and be targets for pharmacotherapy and social rehabilitation.

Key words: patients with cognitive impairment; depressive disorders; clinical and psychopathological features; recurrent depressive disorder; bipolar depressive disorder; prolonged depressive reaction.

Метою дослідження було визначити анамнестичні клініко-психопатологічні особливості депресивних проявів у пацієнтів із когнітивними порушеннями при депресивних розладах.

\section{МАТЕРІАЛИ I МЕТОДИ}

У дослідженні взяли участь 362 пацієнти 3 когнітивними порушеннями при депресивних розладах: 123 осіб із рекурентними депресивними розладами (РДР), 141 пацієнт з біполярними афективними розладами (БАР) та 98 осіб із пролонгованою депресивною реакцією (ПДР). Серед обстежених пацієнтів з РДР було 57 чоловіків $(46,34 \pm 2,78)$ $\%$ і 66 жінок $(53,66 \pm 2,99) \%$, серед пацієнтів 3 БАР було 76 чоловіків $(53,90 \pm 2,61) \%$ та 65 жінок $(46,10 \pm 2,42) \%$, а серед пацієнтів із ПдР було 43 чоловіків $(43,88 \pm 3,39) \%$ та 55 жінок $(56,12 \pm 3,83)$ $\%$, що в цілому відповідає типовому розподілу за статтю при ДР. Тобто серед обстежених переважали особи жіночої статі $(51,96 \%$, ДК=0,66, Ml=0,02, $p=0,046)$, лише в групі пацієнтів із БАР було більше чоловіків (53,90\%, ДК=0,66, Ml=0,02, $\mathrm{p}=0,046)$. Переважна кількість осіб із КП при ДР була у віці 30-44 роки (38,12 \%). Осіб молодого віку (18-29 років) було більше серед пацієнтів із ПДР (21,43 $\%, Д К=8,19, \mathrm{Ml}=0,74, \mathrm{p}=0,0001)$ та серед хворих 3 БAP $(31,21 \%, Д K=9,82, M l=1,37, p=0,0001)$, а осіб середнього віку (45-59 років) та осіб похилого віку (60-65 років) - серед пацієнтів із РДР $(37,40 \%$, ДК=1,54, $\mathrm{Ml}=0,09, \mathrm{p}=0,016$ та $17,07 \%, Д К=4,78$, $\mathrm{Ml}=0,27, \mathrm{p}=0,002$ ).

У дослідженні був використаний комплексний підхід, що полягав у використанні клініко-психопатологічного, клініко-анамнестичного та статистичного методів дослідження. Статистичну обробку даних застосовували для визначення середніх величин кількісних параметрів, їхніх стандартних помилок (у фрорматі \%₫m \%), достовірності відмінностей (критерії Стьюдента - Фішера [t], точний метод Фішера, Колмогорова - Смірнова [ $\lambda]$ ). Статистична обробка результатів проводилась за допомогою Excel-2010 та STATISTICA 6.1.
Вісник медичних і біологічних досліджень Bulletin of Medical and Biological Research
3(5),2020 


\section{РЕЗУЛЬТАТИ Й ОБГОВОРЕННЯ}

Вивчення клініко-психопатологічних особливостей депресивних розладів включало в себе аналіз анамнестичних даних щодо особливостей початку депресії і тривалості хвороби до моменту звернення до лікаря у хворих із депресивними порушеннями. Був проведений ретельний аналіз анамнезу захворювання серед пацієнтів з депресивними порушеннями та особливості початку депресії і тривалості хвороби до моменту звернення до лікаря, результати якого представлені в таблиці, з якої видно, що у більшості пацієнтів із РДР був зафріксований підгострий початок депреciї $(50,41 \pm 2,91) \%$, у 39,84 \% - затяжний початок депресії та у 9,76 \% пацієнтів - гострий початок депресії. Аналіз тривалості поточного епізоду до моменту звернення до лікаря у пацієнтів із РДР продемонстрував, що у більшості з них тривалість поточного епізоду становила період до року, із них: у 26,02 \% - до 3-х місяців, у 49,59 \% - до півроку, в $16,26 \%$ - до року. При цьому тривалість поточного епізоду більше року була зафріксована у незначної кількості пацієнтів з РДР: у 4,88 \% - до 1,5 року, в $2,44 \%$ - до $2-x$ років та у $0,81 \%$ - більше $2-x$ років. Було також визначено, що кількість епізодів в анамнезі у переважної кількості пацієнтів із РДР коливалась у межах від 3-х до 5-ти $(52,85 \pm 2,97) \%$, у 31,71\% пацієнтів кількість епізодів в анамнезі становила від 1-го до 2-х та більше 5-ти епізодів в анамнезі спостерігалось у 15,45 \% пацієнтів з РДР. Було також встановлено, що тривалість попередньої ремісії у 34,96 \% осіб була від 6 до 12 міся- ців, у 36,59 \% - від 12-ти до 24-х місяців та у 28,46 $\%$ пацієнтів - більш 24-х місяців.

У хворих із БАР у більшості був зафіксований гострий початок хвороби $(55,32 \pm 2,64) \%$, у 32,62 $\%$ - підгострий початок та у $12,06 \%$ визначався затяжний початок депресії. Тривалість депресивного епізоду серед пацієнтів з БАР у більшості випадків складала від 3-х місяців до 6-ти місяців $(44,68 \pm 2,37) \%$, у $25,53 \%$ - від 6-ти місяців до 1 року, у 19,15 \% - тривалість становила до 3-х місяців. У незначної кількості обстежених тривалість епізоду становила більше 12-ти місяців: до 1,5 року - в 7,09 \% випадків, до 2-х років - у 2,84 \% пацієнтів та більше 2-х років - у 0,71 \% випадків.

Було встановлено, що у більшості пацієнтів 3 БАР кількість епізодів в анамнезі становила більше 5-ти $(48,94 \pm 2,50) \%$, у 35,46 \% пацієнтів - кількість епізодів в анамнезі була від 3-х до 5-ти, у 15,60 \% пацієнтів з БАР - від 6-ти до 12-ти місяців. Аналіз тривалості попередньої ремісії продемонстрував, що у 46,10 \% пацієнтів вона становила від 6-ти до 12-ти місяців, у 38,30 \% - від 12-ти до 24-х місяців та у $15,60 \%$ - більше $24-x$ місяців.

У пацієнтів із ПДР встановлено, що у більшості хворих початок депресії був затяжним $(62,24 \pm 3,94)$ $\%$, в 20,41 \% випадків визначався підгострий початок та в 17,35 \% випадків - гострий початок депресії. Тривалість поточного епізоду депресії до моменту звернення до лікаря при ПДР у 31,63 \% пацієнтів становила від 12-ти місяців до 18-ти місяців, у 22,45 \% - від 6-ти до 12-ти місяців, у 21,43 $\%$ осіб із ПДР поточний епізод тривав до 2-х років,

Таблиця. Анамнестичні дані щодо особливостей початку депресії і тривалості хвороби до моменту звернення до лікаря у хворих із депресивними порушеннями

\begin{tabular}{|c|c|c|c|c|c|c|}
\hline \multirow{2}{*}{ Найменування показників } & \multicolumn{2}{|r|}{ РДР } & \multicolumn{2}{|c|}{ БАР } & \multicolumn{2}{|r|}{ ПДР } \\
\hline & абс. & $\% \pm m$ & абс. & $\% \pm m$ & абс. & $\% \pm m$ \\
\hline \multicolumn{7}{|l|}{ І. Початок депресії: } \\
\hline - гострий; & 12 & $9,76 \pm 0,76$ & 78 & $55,32 \pm 2,64$ & 17 & $17,35 \pm 1,63$ \\
\hline - підгострий; & 62 & $50,41 \pm 2,91$ & 46 & $32,62 \pm 1,91$ & 20 & $20,41 \pm 1,88$ \\
\hline - затяжний & 49 & $39,84 \pm 2,53$ & 17 & $12,06 \pm 0,81$ & 61 & $62,24 \pm 3,94$ \\
\hline \multicolumn{7}{|c|}{ II. Тривалість поточного епізоду до моменту звернення до лікаря: } \\
\hline - до 3 місяців; & 32 & $26,02 \pm 1,83$ & 27 & $19,15 \pm 1,23$ & 8 & $8,16 \pm 0,81$ \\
\hline - до 6 місяців; & 61 & $49,59 \pm 2,89$ & 63 & $44,68 \pm 2,37$ & 10 & $10,20 \pm 1,00$ \\
\hline - до 1 року; & 20 & $16,26 \pm 1,22$ & 36 & $25,53 \pm 1,57$ & 22 & $22,45 \pm 2,04$ \\
\hline - до 1,5 року; & 6 & $4,88 \pm 0,39$ & 10 & $7,09 \pm 0,49$ & 31 & $31,63 \pm 2,70$ \\
\hline - до 2 років; & 3 & $2,44 \pm 0,20$ & 4 & $2,84 \pm 0,20$ & 21 & $21,43 \pm 1,96$ \\
\hline - більше 2 років & 1 & $0,81 \pm 0,07$ & 1 & $0,71 \pm 0,05$ & 6 & $6,12 \pm 0,61$ \\
\hline \multicolumn{7}{|c|}{ III. Кількість епізодів в анамнезі, враховуючи поточний: } \\
\hline - від 1 до 2; & 39 & $31,71 \pm 2,15$ & 22 & $15,60 \pm 1,02$ & 84 & $85,71 \pm 3,34$ \\
\hline - від 3 до 5; & 65 & $52,85 \pm 2,97$ & 50 & $35,46 \pm 2,03$ & 14 & $14,29 \pm 1,36$ \\
\hline - більше 5 & 19 & $15,45 \pm 1,16$ & 69 & $48,94 \pm 2,50$ & 0 & $0,00 \pm 0,00$ \\
\hline \multicolumn{7}{|c|}{ IV. Тривалість попередньої ремісії: } \\
\hline - від 6 до 12 місяців; & 43 & $34,96 \pm 2,31$ & 65 & $46,10 \pm 2,42$ & 2 & $2,04 \pm 0,21$ \\
\hline - 12-24 місяці; & 45 & $36,59 \pm 2,39$ & 54 & $38,30 \pm 2,15$ & 7 & $7,14 \pm 0,71$ \\
\hline - більше 24 місяців & 35 & $28,46 \pm 1,97$ & 22 & $15,60 \pm 1,02$ & 89 & $90,82 \pm 2,84$ \\
\hline
\end{tabular}


у 10,20 \% пацієнтів - до 6-ти місяців, у 8,16 \% пацієнтів - до 3-х місяців та у 6,12 \% пацієнтів - епізод тривав більше 2-х років. При цьому було визначено, що кількість епізодів у більшості пацієнтів 3 ПДР складало від 1-го до 2-х епізодів (включаючи поточний) $(85,71 \pm 3,34) \%$ та у $14,29 \%$ пацієнтів до 5-ти епізодів в анамнезі. Також було встановлено, що у 90,82 \% тривалість попередньої ремісії була більше 24-х місяців, у 7,14 \% пацієнтів - від 12-ти до 24-х місяців та у 2,04 \% - від 6-ти до 12-ти місяців.

Був проведений статистичний аналіз за допомогою точного методу Фішера (ТМФ) з розрахунком діагностичних коефіцієнтів (ДК) і мір інорормативності Кульбака (MI), які дозволили визначити специфрічні особливості перебігу хвороби для кожної форми депресивного розладу. Так, було встановлено, що гострий початок депресії був більш характерним пацієнтам із БАР $(55,32 \pm 2,64) \%$, ніж хворим із ПДР (17,35 \%, ДК=5,04, MІ=0,96, p<0,0001) та РДР $(9,76 \%, Д К=7,54, \mathrm{MI}=1,72, \mathrm{p}<0,0001)$, а також було визначено, що пацієнтів з гострим початком депресії було більше серед пацієнтів з ПДР $(17,35 \pm 1,63) \%$, ніж з серед пацієнтів з РДР $(9,76 \%$, ДК=2,50, MI=0,09, p<0,041). Підгострий початок був більш притаманний пацієнтам 3 РДР $(50,41 \pm 2,91)$ $\%$, порівняно 3 хворими на БАР $(32,62 \%$, ДК=1,89, $\mathrm{Ml}=0,17, \mathrm{p}<0,0014)$ та на ПДР $(20,41 \%$, ДК=3,93, $\mathrm{Ml}=0,59, p<0,0001)$, при цьому пацієнтів 3 підгострим початком було більше серед пацієнтів з БАР $(32,62 \pm 1,91) \%$, ніж серед пацієнтів 3 ПДР $(20,41$ $\%$, ДК=2,04, MI=0,12, $\mathrm{p}<0,0136)$. Затяжний початок депресії був більш характерним для пацієнтів із ПДР $(62,24 \pm 3,94) \%$, порівняно 3 пацієнтами із БАР $(12,06 \%$, ДК=7,13, MІ=1,79, p<0,0001), та РДР (39,84\%, ДК=1,94, MI=0,22, p<0,0005), у той час, коли затяжний початок був більш виражений серед пацієнтів із РДР $(39,84 \pm 2,53) \%$ порівняно 3 хворими на БАР $(12,06 \%$, ДК=5,19, MI=0,72, $\mathrm{p}<0,0001)$.

Також був проведений статистичний аналіз, який дозволив встановити специфічність тривалості поточного епізоду при різних типах депресивного розладу. Було встановлено, що тривалість поточного епізоду до 3-х місяців була більш характерна для пацієнтів із РДР $(26,02 \pm 1,83) \%$, порівняно 3 хворими на БАР $(19,15 \%$, ДК=1,33, MI=0,05, p<0,049), та ПДР (8,16 \%, ДК=5,03, MI=0,45, p<0,0003), а пацієнтів із БАР з наявністю поточного епізоду до 3-х місяців було більше $(19,15 \pm 0,20) \%$, ніж пацієнтів із ПДР (8,16 \%, ДК=3,70, MI=0,20, p<0,0001). Тривалість епізодів до 6-ти місяців була також більш притаманна пацієнтам 3 РДР $(49,59 \pm 2,89) \%$ та БАР $(44,68 \pm 2,37) \%$, ніж хворим на ПДР $(10,20 \%$, ДК=6,87, $\mathrm{Ml}=1,35, \mathrm{p}<0,0001$ та ДК=6,41, $\mathrm{Ml}=1,11$, p<0,0001 відповідно). Тривалість поточного епізоду до 1-го року була більш характерною для пацієнтів з БАР $(25,53 \pm 1,57) \%$, порівняно 3 хворими на РДР (16,26\%, ДК=1,96, МІ=0,09, p<0,0225), у той час, коли тривалість поточного епізоду від 12ти до 18-ти місяців, від 1,5 до 2-х років та більше 2-х років була більш характерною для хворих 3 ПДР (31,63 \%, 21,43 \% та 6,12 \% відповідно), ніж для пацієнтів із БАР (7,09\%, ДК=6,49, МІ=0,80, $\mathrm{p}<0,0001 ; 2,84 \%$, ДК=8,78, МІ=0,82, $\mathrm{p}<0,0001$ та 0,71 \%, ДК=9,36, Мl=0,25, p<0,0184 відповідно) та РДР (4,88 \%, ДК=8,12, МІ=1,09, p<0,0001; 2,44 $\%$, ДК=9,44, МІ=0,90, р<0,0001та 0,81 \%, ДК=8,77, $\mathrm{Ml}=0,23, \mathrm{p}<0,0279$ відповідно).

При аналізі кількості епізодів в анамнезі були визначені відмінності між групами, що дозволили констатувати, що серед пацієнтів із ПДР було більше осіб з одиночним епізодом $(85,71 \pm 3,34) \%$, ніж серед пацієнтів з РДР (31,71 \%, ДК=4,32, MI=1,17, $\mathrm{p}<0,0001)$ та БАР $(15,60 \%$, ДК=7,40, $М \mathrm{l}=2,59$, $\mathrm{p}<0,0001)$, у той час, коли серед хворих на РДР було більше пацієнтів 3 1-2 епізодами в анамнезі $(31,71 \pm 2,15) \%$, ніж це було характерно для пацієнтів з БАР $(15,60 \%$, ДК=3,08, $\mathrm{Ml}=0,25, p<0,001)$. Пацієнти з РДР відрізнялись від хворих на БАР (35,46 \%, ДК=1,73, MI=0,15, p<0,0018) та ПДР $(14,29 \%$, ДК=5,68, MI=1,10, p<0,0001) більшою кількістю пацієнтів, в анамнезі яких було від 3-х до 5-ти епізодів $(52,85 \pm 2,97) \%$, а серед пацієнтів із БАР було більше пацієнтів, в анамнезі яких було від 3-х до 5-ти депресивних епізодів $(35,46 \pm 2,03) \%$ порівняно з пацієнтами з ПДР (14,29 \%, ДК=5,04, $\mathrm{Ml}=0,96, \mathrm{p}<0,0001)$. Серед пацієнтів з БАР було більше пацієнтів з кількістю епізодів більше 5-ти $(48,94 \pm 2,50) \%$, ніж це було характерно для хворих на РДР (15,45\%, ДК=5,01, MI=0,84, p<0,0001) та ПДР (0 \%, р<0,0001). При цьому серед пацієнтів із РДР з наявністю більше 5-ти епізодів в анамнезі було більше $(15,45 \pm 1,16) \%$, ніж серед хворих на ПДР $(\mathrm{p}<0,0001)$.

у статистичному аналізі визначались також особливості тривалості попередньої ремісії. Було встановлено, що найбільш тривала ремісія (більше 24 місяці) була характерна для пацієнтів 3 ПДР $(90,82 \pm 2,84) \%$, ніж $з$ БАР $(15,60 \%$, ДК=7,65, $\mathrm{Ml}=2,88, \mathrm{p}<0,0001)$ та РДР $(28,46 \%$, ДК=5,04, $\mathrm{Ml}=1,57, \mathrm{p}<0,0001)$, для яких були більш характерна тривалість попередньої ремісії від 6 до 12 місяців (46,10\%, ДК=13,54, MI=2,98, p<0,0001 та 34,96 \%, ДК=12,34, MI=2,03, p<0,0001 відповідно) та від 12 до 24-х місяців (38,30 \%, ДК=7,29, $\mathrm{Ml}=1,14, \mathrm{p}<0,0001$ та 36,59\%, ДК=7,09, $\mathrm{Ml}=1,04$, p<0,0001 відповідно). При цьому було також встановлено, що серед пацієнтів із БАР було більше осіб, в яких ремісія складала від 6-ти до 12-ти місяців $(46,10 \pm 2,42)$ \% порівняно 3 пацієнтами з РдР (34,96 \%, ДК=1,20, MI=0,07, p<0,0186), а у пацієнтів з РДР було більше осіб з тривалістю ремісії більше 24 місяців $(28,46 \pm 2,42) \%$, ніж при БАР $(15,60 \%$, ДК=2,61, $\mathrm{MI}=0,17, \mathrm{p}<0,0049)$.
Вісник медичних і біологічних досліджень Bulletin of Medical and Biological Research
$3(5), 2020$ 


\section{висновки}

Були встановлені специфрічні особливості перебігу депресивного розладу в пацієнтів із КП при різних типах ДР:

- у пацієнтів із РДР переважали підгострий $(50,41 \%)$ та затяжний $(39,84 \%)$ початки депресії; тривалість депресивного епізоду - від 3-х до 6-ти місяців (26,02 \% та 49,59 \% відповідно); переважання 3-5 (52,85 \%) та 1-2 епізодів в анамнезі (26,02 \%); тривалість ремісії від 12-ти до 24-х місяців (36,59\%);

- в осіб із БАР переважали гострий $(55,32 \%)$ та підгострий (32,62 \%) початки депресії; тривалість депресивного епізоду - від 6-ти місяців до 1 року (44,68 \% та 25,53 \% відповідно); переважання
3-5 (35,46 \%) та більше 5-ти епізодів в анамнезі (46,94 \%); тривалість ремісії від 6-ти до 12-ти місяців $(46,10 \%)$;

- у пацієнтів із ПДР переважали затяжний $(62,24 \%)$ та підгострий $(20,41 \%)$ початки депресії; тривалість депресивного епізоду «до року» $(22,45$ $\%)$, «до 1,5 року» (31,65 \%) та «до 2-х років» $(21,43$ $\%)$; переважання 1-2 епізодів в анамнезі (85,71\%); тривалість ремісії більше 24 місяців (90,82 \%).

Таким чином, у результаті дослідження були визначені особливості перебігу депресивного розладу в пацієнтів із КП при різних типах ДР, які можуть виступати в якості діагностичних критеріїв при проведенні дисреренційної діагностики та розробки стратегії лікування КП при ДР.

\section{СПИСОК ЛІТЕРАТУРИ}

1. Комплексный план действий в области психического здоровья на 2013-2020 гг. [Электронный ресурс]. Женева : ВО3, 2013. Режим доступа: http://apps.who.int/ gb/ebwha/pdf files/WHA66/A66_R8-ru.pdf?ua=1

2. Depression: a global public health concern / M. Marcus M. T. Yasamy, M. van Ommeren [et al.]. Geneva, Switzerland: World Health Organization, 2012.

3. Бедлінський В. О. Порівняльна характеристика депресії у хворих, які перенесли черепно-мозкову травму, та у пацієнтів з ендогенними афективними розладами настрою / В. О. Бедлінський // Архів психіатрії. - 2017. - № 23. - C. 33-36.

4. Barton B. Die depressive Symptomatik muss "übersetzt" warden / B. Barton // DNP-Der Neurologe \& Psychiater. - 2017. - Vol. 18 (3). - P. 35-44. DOI: https:// doi.org/10.1007/s15202-017-1598-6.

5. Saltiel P. F. Major depressive disorder: mechanismbased prescribing for personalized medicine / P. F. Saltiel, D. I. Silvershein // Neuropsychiatr. Dis. Treat. - 2015. Vol. 11. - P. 875-888.

6. Eschweiler G. W. Diagnostik und multimodale Therapie der Altersdepression: Diagnostics and multimodal treatment of depression in old age / G. W. Eschweiler // Zeitschrift für Gerontologie und Geriatrie. -2017. - Vol. 50 (2). - P. 99-105. DOI: 10.1007/s00391-016-1174-2.

7. Maslow G. R. Depression and suicide in children and adolescents / G. R. Maslow, K. Dunlap, R. J. Chung //

\section{REFERENCES}

1. Comprehensive mental health action plan 20132020. [Electronic resource]. Geneva: WHO, 2013. Available from: http://apps.who.int/gb/ebwha/pdf_files/WHA66/A66_ R8-ru.pdf?ua=1 Russian

2. Marcus M, Yasamy MT, van Ommeren M. Depression: a global public health concern. Geneva, Switzerland: World Health Organization, 2012

3. Bedlinsky VO [Comparative characteristic of depression in ailments, who have suffered cranio-cerebral trauma, and in patients with endogenous affective disorders of the mood]. Arkhiv psykhiatrii. 2017;23: 33-6. Ukrainian.

4. Barton B. Die depressive Symptomatik muss

Pediatr. Rev. - 2015. - Vol. 36 (7). - P. 299-308; quiz 9-10. Epub 2015/07/03. DOI: 10.1542/pir. 36-7-299.

8. Exploratory analyses of efficacy data from major depressive disorder trials submitted to the US Food and Drug Administration in support of new drug applications / N. Khin, Y. Chen, Y. Yang [et al.] // J. Clin. Psychiatry. 2011. - Vol. 72 (4). - P. 464-472.

9. Westen D. Prototype diagnosis of psychiatric syndromes / D. Westen // World Psychiatry. - 2012. Vol. 11. - P. 12-21.

10. Марута Н. О. Діагностичні критерії депресивних розладів на етапах надання медичної допомоги / Н. О. Марута, Т. В. Панько, Г. Ю. Каленська // Український вісник психоневрології. - 2017. - Т. 25, № 1 (90). - С. 135.

11. Corp S. A. A review of the use of stimulants and stimulant alternatives in treating bipolar depression and major depressive disorder / S. A. Corp, M. J. Gitlin, L. L. Altshuler // J. Clin. Psychiatry. - 2014. - Vol. 75. - P. 1010-1018.

12. Марута Н. А. Нейротрофическая терапия депрессий: возможности и перспективы / Н. А. Марута, И. А. Явдак, Е. С. Череднякова // Международный неврологический журнал. - 2014. - № 4(66). - С. 70-79.

13. Does duloxetine improve cognitive function independently of its antidepressant effect in patients with major depressive disorder and subjective reports of cognitive dysfunction? / T. L. Greer, P. Dunderajan, B. D. Grannemann [et al.] // Depress. Res. Treat. - 2014. - P. 1-13.

"übersetzt" warden. DNP-Der Neurologe \& Psychiater. 2017;18(3): 35-44. DOI: https://doi.org/10.1007/s15202017-1598-6.

5. Saltiel PF, Silvershein DI. Major depressive disorder: mechanism-based prescribing for personalized medicine. Neuropsychiatr Dis Treat. 2015;11: 875-88.

6. Eschweiler GW. Diagnostik und multimodale Therapie der Altersdepression: Diagnostics and multimodal treatment of depression in old age. Zeitschrift für Gerontologie und Geriatrie. 2017;50(2): 99-105. DOI: 10.1007/s00391-0161174-2.

7. Maslow GR, Dunlap, RJ. Chung K. Depression 
and suicide in children and adolescents. Pediatr Rev. 2015;36(70): 299-308; quiz 9-10. Epub 2015/07/03. DOI: 10.1542/pir. 36-7-299.

8. Khin $\mathrm{N}$, Chen $\mathrm{Y}$, Yang $\mathrm{Y}$, Yang $\mathrm{P}$, Laughren $\mathrm{T}$. Exploratory analyses of efficacy data from major depressive disorder trials submitted to the US Food and Drug Administration in support of new drug applications. J Clin Psychiatry 2011;72(4): 464-72.

9. Westen D. Prototype diagnosis of psychiatric syndromes. World Psychiatry 2012;11: 12-21.

10. Maruta NO, Panko TV, Kalenska GYu. [Diagnostic criteria for depressive disorders at stages of providing medical aid]. Ukrainskyi visnyk psykhonevrolohii. 2017;25:1(90): 135. Ukrainian.
11. Corp SA, Gitlin MJ \& Altshuler LL A review of the use of stimulants and stimulant alternatives in treating bipolar depression and major depressive disorder. J Clin Psychiatry. 2014;75: 1010-18.

12. Maruta NA, Yavdak IA, Cherednyakova ES. [Neurotrophic therapy for depression: opportunities and prospects]. Mezhdunarodnyy nevrologicheskiy zhurnal. 2014;4(66): 70-9. Russian.

13. Greer TL, Dunderajan P, Grannemann BD, Kurian BT, Trivedi $\mathrm{MH}$. Does duloxetine improve cognitive function independently of its antidepressant effect in patients with major depressive disorder and subjective reports of cognitive dysfunction? Depress Res Treat. 2014: 1-13.

Отримано 03.08.20 